\title{
Different Sample Preparation Methods for Glomerular Morphological Evaluation: To Coat or not to Coat?
}

\author{
Diferentes Métodos de Preparación de Muestras para la \\ Evaluación Morfológica Glomerular ¿Recubrir o no Recubrir?
}

\begin{abstract}
Priscila Fernandes dos Santos ${ }^{1}$; Diogo Benchimol de Souza ${ }^{1}$; Eduardo José Lopes Torres²; Waldemar Silva Costa ${ }^{1}$; Francisco José Barcelos Sampaio ${ }^{1}$ \& Bianca Martins Gregorio ${ }^{1}$
\end{abstract}

DOS SANTOS, P. F.; DE SOUZA, D. B.; TORRES, E. J. L.; COSTA, W. S.; SAMPAIO, F. J. B. \& GREGORIO, B. M. Different sample preparation methods for glomerular morphological evaluation: To coat or not to coat? Int. J. Morphol., 37(2):477-480, 2019.

SUMMARY: The renal glomerulus is coated by fenestrated endothelial cells and externally covered by specialized epithelial cells, known as podocytes. Scanning electron microscopy becomes an important and effective tool for its studies. Normally, samples destined for scanning microscopy are covered with a thin metallic layer. However, this step can be dispensed for some analyzes. We aimed to compare coated and uncoated samples for evaluation of the glomerular morphology of the Wistar rat kidney. Cortical region of the kidney of the 5month-old male Wistar rats were used. The fragments followed the routine procedure for scanning electron microscopy processing. Half of 10 fragments were coated with palladium gold and the remaining were not coated.Auriga Compact FIB - SEM scanning electron microscope was used to observe the samples. Different increases and voltages was evaluated. For the uncoated samples, when using voltages of $2 \mathrm{KV}$ (or higher) a great charging was observed, impairing the use of such voltage. Thus, these samples were always observed under voltage of $0.5 \mathrm{KV}$. On the other hand, in the coated samples, the use of $2 \mathrm{KV}$ was adequate. Almost as a consequence, in the coated samples, the podocyte structures were better characterized, generating better images. Inversely, in the uncoated samples, it was possible to visualize the desired structures and to detect the morphological characteristics of these. The results showed that it is possible to use kidney samples without previous coating to evaluate the glomerular morphology at the ultrastructural level, serving as a tool in the study of pathologies.

KEY WORDS: Glomerular morphology; Renal filtration barrier; Scanning electron microscopy.

INTRODUCTION

The kidneys are functionally important organs, since they act in the control of the systemic arterial pressure, on the production of certain hormones, and mainly in the mechanism of blood filtration. From the anatomical point of view, they are located laterally to the vertebral column, and are surrounded by a fibrous capsule (renal capsule) and a mass of adipose tissue (peri and pararenal fats). Internally, two regions are distinguished in the renal parenchyma: the cortex (out region) and the medulla (inner region), with innumerable tubules and renal corpuscles (nephrons). The renal corpuscles have numerous tortuous arterioles covered by podocytes, where the whole endothelial layer of these arterioles, their basement membrane and the podocytes correspond to the glomerular filtration barrier (Bloom \& Fawcett, 1975; Jarad \& Miner, 2009).

The renal glomerulus is a spherical capillary tuft contained by Bowman's capsule, and responsible for performing the selective filtration of the circulating blood for the formation of the primordial urine. These capillaries are coated by fenestrated endothelial cells and externally covered by specialized epithelial cells, known as podocytes (Lennon et al., 2014). These differentiated epithelial cells consist of a body from which several prolongations, called foot processes, emerge. The interdigitation with the foot processes of the neighbor podocyte, creates what is known as the slit diaphragm (Relle et al., 2011). It is of interest to analyze the glomerular ultrastructure (especially of the slit diaphragm), since some diseases promote changes in this normal morphology. In this sense, scanning electron microscopy (SEM) becomes an important and effective tool for these studies (de Souza et al., 2016). Normally, samples destined for scanning microscopy are covered with a thin metallic layer (more commonly of gold or palladium-gold) to make the sample conductive of electric charges. However, this step can be dispensed for some analyzes, reducing and

\footnotetext{
${ }^{1}$ Urogenital Research Unit, Biomedical Center, State University of Rio de Janeiro, Rio de Janeiro, Brazil.

${ }^{2}$ Department of Microbiology, Immunology and Parasitology, Biomedical Center, State University of Rio de Janeiro, Rio de janeiro, Brazil.
} 
accelerating the sample preparation process. Then, we aimed to compare coated and not coated samples for evaluation of the glomerular morphology of the Wistar rat kidney.

\section{MATERIAL AND METHOD}

All procedures were approved by the local Ethics Committee for the Care and Use of Animals (CEUA, IBRAG / 049/16). Ten male Wistar rats were housed in polypropylene boxes in climatized colony rooms $\left(21 \pm 2{ }^{\circ} \mathrm{C} ; 60 \%\right.$ humidity) on a 12/12 h light/dark cycle with an air exhaustion cycle (15 $\mathrm{min} / \mathrm{h}$ ) from weaning to 5 months old. During the experiment, the animals received food and water ad libitum. On sacrifice, the rats were killed by anesthetic overdose. Immediately after death, the abdominal region was opened, the right kidney was excised and sliced to SEM. Ten fragments of approximately $1 \mathrm{~mm}^{2}$ of the cortical region of the kidney of the 5 month old male Wistar rat were used. The fragments were fixed by immersion with $2.5 \%$ glutaraldehyde in phosphate buffer $(\mathrm{pH}$ 7.3) and post-fixed in $1 \% \mathrm{O}_{\mathrm{s}} \mathrm{O}_{4}$ for 40 minutes. Soon after, they were washed three times in phosphate buffer and dehydrated in increasing order of ethanol in the concentrations of $20 \%, 30 \%, 50 \%, 70 \%, 90 \%$ and three times of absolute, for $20 \mathrm{~min}$ each. The fragments were then dried at critical point with liquid $\mathrm{CO}_{2}$ and mounted on metal supports. Of the ten fragments, five were coated with palladium gold for 1 minute, to obtain coverage of approximately $20 \mathrm{~nm}$ and the remaining fragments were not coated. The samples were observed in the Auriga Compact FIB - SEM of the Urogenital Research Unit - UERJ. In these samples we sought to obser- ve the inter-digitations of the glomerular foot process and the quality of the image obtained in different increases and voltages was evaluated.

\section{RESULTS}

In all samples (coated or not coated), ultrastructural glomerular morphology could be observed (Fig. 1). For the uncoated samples, when using voltages of $2 \mathrm{KV}$ (or higher) a great charging was observed, impairing the use of such voltage. Thus, these samples were always observed under voltage of $0.5 \mathrm{KV}$. On the other hand, in the coated samples, the use of 2 $\mathrm{KV}$ was adequate. Almost as a consequence, in the coated samples, the podocyte structures were better characterized, generating better images. Therefore, in the uncoated samples, it was possible to visualize the desired structures and to detect the morphological characteristics of these.

\section{DISCUSSION}

Traditionally, the metallization of biological materials represents an important step, since it makes them conductive and prevents the accumulation of negative charges on the surface of the sample due to the interaction with the transfers electrons. In addition, the coating allows the higher emission of secondary electrons, thus increasing the contrast and facilitating the obtaining of images with greater detail of information (Pretorius, 2011).



Fig. 1. Glomerular ultrastructure. Coated samples showed in A, B, C and uncoated samples showed in D, E, F. (A) General morphology of the glomerulus; (B) glomerular ultrastructure: the cell body $[\mathrm{CB}]$ of the podocytes $[\mathrm{P}]$ and foot process $[\mathrm{FP}]$; (C) podocytes $[\mathrm{P}]$ and foot process [FP]; (D) General morphology of the glomerulus, (E) and (F) shows the podocytes [P] and foot process [FP]. 
In studies of coated samples, there are two ways of covering the materials: thermal evaporation in high vacuum and sputtering, considered the most efficient and therefore the choice for carrying out the present work (Mannheimer, 2002). However, it is common that a research laboratory with large numbers of Young researchers not present any metallizers. Thus, a viable alternative would be the use of low acceleration voltage by transfers electrons. The only disadvantage to this could be the compromising of the three-dimensional aspect of the image (Pretorius).

In this way, we used coated and uncoated kidneys samples (cortex) in order to observe the glomerular morphology. We have seen that the podocyte structures were better characterized when the samples were metallized. However, the use of low voltages for the observation of uncoated samples was able to reveal the surface of the sample, allowing analysis of themorphology and the state of the glomerular function. Furthermore, uncoated material allows the SEM technique to be executed faster and cheaper, which makes it possible to maintain scientific research in a scenario of economic crisis. Souza et al. (2013) described a morphometric technique to quantify the length of foot process in coated samples. It is known that the integrity of the filtration barrier components is fundamental for renal health, and the effacement of the foot process may be indicative of kidney dysfunction, as seen by Kim et al. (2017). This technique could be easily reproduced in uncoated samples, due to the preservation of the glomerular ultrastructure found in our study. It should be noted that this alternative to the conventional method was ensured by the fact that the microscope used here has a field emission electron source, which is an advantage over tungsten filament microscopes. Obviously, more studies are needed to validate this technique in uncoated materials.

The results showed that it is possible to use kidney samples without previous coating to evaluate the glomerular morphology at the ultrastructural level, serving as a tool in the study of pathologies. However, whenever possible, coating should be preferred as it enables higher quality images.

\section{ACKNOWLEDGMENTS}

This research was supported by Brazilian agencies FAPERJ (E-26/010.002569/2014). We would like to thank Makoto Enoki Caracciolo ( $\mathrm{PhD}$ student) for his assistance during the processing of samples for SEM. The authors declare that there are no conflicts of interest.
DOS SANTOS, P. F.; DE SOUZA, D. B.; TORRES, E. J. L.; COSTA, W. S.; SAMPAIO, F. J. B. \& GREGORIO, B. M. Diferentes métodos de preparación de muestras para la evaluación morfológica glomerular: ¿recubrir o no recubrir? Int. J. Morphol., 37(2):477-480, 2019.

RESUMEN: El glomérulo renal está recubierto por células endoteliales fenestradas y cubierto externamente por células epiteliales especializadas, conocidas como podocitos. La microscopía electrónica de barrido se convierte en una herramienta importante y efectiva para sus estudios. Normalmente, las muestras destinadas a microscopía de barrido se cubren con una capa metálica delgada. Sin embargo, este paso se puede dispensar para algunos análisis. El objetivo fue comparar muestras recubiertas y no recubiertas para evaluar la morfología glomerular del riñón de rata Wistar. Se utilizó la región cortical del riñón de ratas Wistar macho de 5 meses de edad. Se realizó el procedimiento de rutina para el procesamiento de microscopía electrónica de barrido. La mitad de 10 fragmentos se recubrieron con oro paladio y los restantes no se recubrieron. Se utilizó un microscopio electrónico de barrido SEM Auriga Compact FIB para observar las muestras. Se evaluaron diferentes aumentos y voltajes. Para las muestras no recubiertas, al usar voltajes de $2 \mathrm{KV}$ (o más) se observó una gran carga, impidiendo el uso de dicho voltaje. Por lo tanto, estas muestras siempre se observaron a bajo voltaje de $0,5 \mathrm{KV}$. Por otro lado, en las muestras recubiertas, el uso de $2 \mathrm{KV}$ fue adecuado. Como consecuencia, en las muestras recubiertas, las estructuras de los podocitos se caracterizaron mejor, generando mejores imágenes. Inversamente, en las muestras no recubiertas, fue posible visualizar las estructuras deseadas y detectar las características morfológicas de éstas. Los resultados mostraron que es posible utilizar muestras de riñón sin recubrimiento previo para evaluar la morfología glomerular a nivel ultraestructural, que sirve como una herramienta en el estudio de patologías.

PALABRAS CLAVE: Morfología glomerular; Barrera de filtración renal; Microscopía electrónica de barrido.

\section{REFERENCES}

Bloom, W. \& Fawcett, D. W. A Textbook of Histology. $10^{\text {th }}$ ed. Philadelphia, Saunders, 1975.

de Souza, D. B.; Gregorio, B. M.; Benchinol, M. \& Nascimento, F. A. M. Evaluation of the Glomerular Filtration Barrier by Electron Microscopy. In: Janecek, M. (Ed.). Modern Electron Microscopy in Physical and Life Sciences. London, InTech, 2016. pp.187-206.

Jarad, G. \& Miner, J. H. Update on the glomerular filtration barrier. Curr. Opin. Nephrol. Hypertens., 18(3):226-32, 2009.

Kim, A. H.; Chung, J. J.; Akilesh, S.; Koziell, A.; Jain, S.; Hodgin, J. B.; Miller, M. J.; Stappenbeck, T. S.; Miner, J. H.\& Shaw, A. S. B cell-derived IL-4 acts on podocytes to induce proteinuria and foot process effacement. J. C. I. Insight, 2(21):81836, 2017.

Lennon, R.; Randles, M. J. \& Humphries, M. J. The importance of podocyte adhesion for a healthy glomerulus. Front. Endocrinol. (Lausanne), 5:160, 2014.

Mannheimer, W. A. Microscopia dos Materiais - Uma Introdução. Rio de Janeiro, E-papers, Serviços Editoriais, 2002. 
DOS SANTOS, P. F.; DE SOUZA, D. B.; TORRES, E. J. L.; COSTA, W. S.; SAMPAIO, F. J. B. \& GREGORIO, B. M. Different sample preparation methods for glomerular morphological evaluation: To coat or not to coat? Int. J. Morphol., 37(2):477-480, 2019.

Pretorius, E. Traditional coating techniques in scanning electron microscopy compared to uncoated charge compensator technology: looking at human blood fibrin networks with the ZEISS ULTRA Plus FEG-SEM. Microsc. Res. Tech., 74(4):343-6, 2011.

Relle, M.; Cash, H.; Brochhausen, C.; Strand, D.; Menke, J.; Galle, P. R. \& Schwarting, A. New perspectives on the renal slit diaphragm protein podocin. Mod. Pathol., 24(8):1101-10, 2011.

Souza, D. B.; Costa, W. S.; Cardoso, L. E.; Benchimol, M.; PereiraSampaio, M. A. \& Sampaio, F. J. Does prolonged pneumoperitoneum affect the kidney? Oxidative stress, stereological and electron microscopy study in a rat model. Int. Braz. J. Urol., 39(1):30-6, 2013.
Corresponding author:

Bianca Martins Gregorio

Unidade de Pesquisa Urogenital

Centro Biomédico

Universidade do Estado do Rio de Janeiro

Av. 28 de Setembro 87 (fds) 20551-030

Rio de Janeiro

BRAZIL

Email: biancamgregorio.uerj@gmail.com URL: www.urogenitalresearch.org

Received: 29-11-2018

Accepted: 29-01-2019 